\title{
The Influence of Reading Purpose on Inference Generation and Comprehension in Reading
}

\author{
Darcia Narvaez and Paul van den Broek \\ University of Minnesota-Twin Cities Campus
}

\author{
Angela Barrón Ruiz \\ University of Salamanca
}

\begin{abstract}
There are variations in the extent to which particular types of inferences or activations are made during reading (G. McKoon \& R. Ratcliff, 1992; M. Singer, 1994). In this study, the authors investigated the influence of reading purpose (for entertainment or study) on inference generation. Participants read 2 texts aloud and 2 texts for comprehension measures. Reading purpose did not influence off-line behavior (comprehension) but did influence on-line reader behavior (thinking aloud). Readers with a study purpose more often repeated the text, acknowledged a lack of background knowledge, and evaluated the text content and writing than did readers with an entertainment purpose. This pattern was stronger for the expository text than for the narrative text. Reading purpose, and possibly text type, affects the kinds of inferences that readers generate. Hence, inferential activities are at least partially under the reader's strategic control.
\end{abstract}

In this study we examined the influence of reading purpose on the type of inferential activities that readers perform. More specifically, we examined the effects of a particular reading purpose (for study or for entertainment) on comprehension behaviors during reading.

Researchers have done a considerable amount of work on inference generation in reading. Some investigations (e.g., Graesser, Singer, \& Trabasso, 1994; O'Brien, Shank, Myers, \& Rayner, 1988; see Singer, 1994, for a review) are based on speeded techniques in which one element is probed for activation during reading. Other investigations of inference generation (e.g., Pressley \& Afflerbach, 1995; Trabasso \& Magliano, 1996; Trabasso \& Suh, 1993; Zwaan \& Brown, 1996) elicit think-aloud protocols in which a continuous record of inferences is produced. In think-aloud research (Pressley \& Afflerbach, 1995) readers have demonstrated a variety of reactions to text. Trabasso and Magliano identified three kinds of working memory operations occurring in think-aloud protocols: (a) activation of relevant world knowledge, (b) maintenance of information in working

Darcia Narvaez, College of Education and Human Development, University of Minnesota-Twin Cities Campus; Paul van den Broek, Department of Educational Psychology, University of Minnesota-Twin Cities Campus; Angela Barrón Ruiz, Faculty of Philosophy and Educational Sciences, University of Salamanca, Salamanca, Spain.

This research was conducted with the support of the Center for Research in Learning, Perception, and Cognition and the National Institute of Child Health and Human Development (HD-07151) and by Grant $\mathrm{II}-\mathrm{C} 9102 \mathrm{~b}$ from the Comite Conjunto HispanoAmericano Para la Cooperación Cultural y Educativa. We thank Melissa Allison, Sarika Garga, and Manda Bharati for their assistance in the completion of this study and Rolf Zwaan for his suggestions on a draft.

Correspondence concerning this article should be addressed to Darcia Narvaez, 150 Peik Hall, 159 Pillsbury Drive Southeast, Minneapolis, Minnesota 55455. Electronic mail may be sent to narvaez@tc.umn.edu. memory, and (c) retrieval of text and prior thoughts from long-term memory. They noted that these were functionally necessary to the three kinds of inferences that they found: backward inferences (explanations), concurrent inferences (associations), and forward inferences (predictions) (see also van den Broek, 1990). The three kinds of inferences are explained as follows. Explanations concern the reasons why something occurs, such as motive, physical cause, or enabling condition. These are generated in a wide variety of reading situations (e.g., Trabasso, van den Broek, \& Suh, 1989; van den Broek, Fletcher, \& Risden, 1993). Associations provide information on the features and functions of persons, objects, and events in the text. Researchers have found considerable evidence that associative inferences are not routinely generated during normal reading (e.g., Graesser, Singer, \& Trabasso, 1994; McKoon \& Ratcliff, 1992). Predictions are inferences made by readers about future consequences of a focal event. Predictive inferences are hard to measure and are hard to find except when a coherence break is resolved (Murray, Klin, \& Myers, 1993), when the prediction is causally constrained within the text (Murray et al., 1993), or when the prediction is specifically foregrounded in the text (Whitney, Ritchie, \& Clark, 1991).

There are variations in the extent to which particular types of inferences or activations are made (McKoon \& Ratcliff, 1986; Singer, 1994), and researchers have become increasingly interested in determining the circumstances that lead to particular inferences. A considerable number of studies have focused on the effects of reader characteristics on inferential activity. For example, inferences have been found to differ as a function of language skill (Horiba, 1990; Horiba, van den Broek, \& Fletcher, 1993; Zwaan \& Brown, 1996), reading ability (Wolman, 1991; Wolman, van den Broek, \& Lorch, 1997), background knowledge (e.g., readers with expert background knowledge do more explaining; Chi, Feltovich, \& Glaser, 1981; Chiesi, Spilich, \& Voss, 1979), and analysis (e.g., Lundeberg, 1987; Wineberg, 1991). Whereas these studies have focused on differences between 
readers, much less attention has been given to the possibility that inferential activities may also differ within an individual reader.

One factor likely used in determining intraindividual variation in the pattern of inferential activity during reading is reading purpose (e.g., Walker \& Meyer, 1980). A critical role for reading purpose in the comprehension process is implicated by findings that orientation to (or goal while reading) the text during reading influences recall (e.g., Anderson \& Pichert, 1978; Pichert \& Anderson, 1977). Furthermore, readers claim to modify their reading strategies according to reading purpose. For example, Lorch, Lorch, and Klusewitz (1993) asked readers what different kinds of reading tasks they experienced and how they perceived the processing demands for the different types of reading tasks. The participants broadly distinguished two categories of reading tasks: reading for school (study) purposes and reading for stimulation (entertainment purposes). Study reading was perceived as less interesting, slower, and more taxing of understanding and memory. It was also perceived to involve less anticipation of future text events, more attempts at integration, and more rereading. In contrast, entertainment reading was perceived to involve increased effort in finding relations among ideas and events in the text, more anticipation of forthcoming text events, more interest, and more analysis of writing style. Lorch et al. provided a rich description of text types and reader perception of their demands. It is unclear, however, what readers actually do when they read with different purposes in mind.

The aim of the present study was to assess inferences readers make under different reading orientations. To do so, we contrasted reading for entertainment and reading for study. These two purposes reflect the most frequent distinction that readers make in their introspections about their own reading behaviors (Lorch et al., 1993) and thus are likely to evoke differences in inferential behaviors. If readers are sensitive to the purposes with which they read and are able to modulate their comprehension activities accordingly, we would expect to find differences in the inferences that are generated. It is also possible, however, that readers do not adjust their comprehension activities according to their purposes. This is likely to occur, for example, if inference generation is largely automatic or bottom-up (i.e., text driven; McKoon \& Ratcliff, 1992). In this case, no differences would occur.

Differences in inference generation may be quantitative or qualitative. One possibility is that a particular purpose for reading affects the overall amount of inferential activity but not the types of inferences that are generated. It is also possible, however, that reading purpose influences how the reader allocates his or her attention and hence what types of inferences are generated. For example, on the basis of readers' introspections, one would expect that reading with a study purpose would result in slower reading and a greater number of text-based inferences than would reading with an entertainment purpose (Lorch et al., 1993). Detailed analyses of the patterns of inference generation allowed us to evaluate each of these possible scenarios: no differences, quantitative differences, or qualitative differences.
Our primary interest was in the comprehension process as it takes place on-line (i.e., during actual reading). We used two measures for on-line processing: activities (during thinking aloud) and speed (reading time). The combination of measures made it possible to obtain converging evidence. Because reading times and think-aloud responses cannot be measured at the same time, we measured them on separate sets of texts. Although of secondary importance in this study, two off-line measures were used-recall and responses to comprehension questions-to test readers' representation of the texts once reading was completed. Again, we used two measures to provide converging evidence.

In selecting materials for this study, we chose to include two different types of text: expository and narrative. Regardless of text type, reading task components (such as translation of symbols to meaning and linguistic structures) are the same, as are the cognitive "hard- and software" (such as background knowledge and working memory capacity of the individual). Indeed, although most evidence on inferential processes during reading is based on studies that used experimenter-generated narrative texts, similar processing has been observed with expository texts (Goldman \& Varma, 1995) and literary texts (van den Broek, Rohleder, \& Narvaez, 1996). However, systematic differences in how people respond to different types of texts, particularly narrative versus expository texts, also have been observed (e.g., Einstein, McDaniel, Owen, \& Coté, 1990; McDaniel, Einstein, Dunay \& Cobb, 1986; Zwaan, 1994). By including texts of each type, we allowed for the greatest generalizability of the results and hoped to obtain preliminary evidence for inference pattern similarities and differences between the text types.

\section{Method}

\section{Participants}

Twenty undergraduate students from a large midwestern university who were enrolled in psychology courses participated in this study. They received course credit for their participation. There were 5 men and 15 women, ranging in age from 19 to 39 years $(M=23.14)$. Nine students majored in a science field, 5 had undeclared majors, and the remaining 6 students majored in the humanities or in education. All were native speakers of English. The groups for the two conditions had virtually equal ratios of men and women and similar proportions of participants majoring in science.

\section{Materials}

Texts. Participants read four short texts: two narrative literary texts and two expository texts. One text of each type was used for think-aloud protocols. The participants read the two other textsone of each type-silently, and answered comprehension questions about the texts (see Procedure, below). The narrative texts were "Spa" (34 sentences, 116 clauses) and "All About Suicide" (31 sentences, 116 clauses). "Spa" is a fictional story by Carmen Martin Gaite (1993) about a bellboy who hears strange sounds from a hotel room and, after a long decision process, breaks into the room to save the woman in the room. An excerpt illustrates the narrative style: "The bellboy stops knocking for a moment and 
sticks his ear to the door; he doesn't know whether to go in or leave" (p. 3). "All About Suicide" is a fictional story by Luisa Valenzuela (1988) about a politician contemplating suicide. The expository texts were "Comet Fire" (19 sentences, 81 clauses) and "Viruses" ( 23 sentences, 82 clauses). Both these texts were used in previous research on the comprehension of expository texts (De Vega, 1990) and typify the kinds of information encountered in textbooks. "Comet Fire," adapted from Time Magazine (Angier, 1985), is about scientific theory and evidence concerning what caused the eradication of the dinosaurs. An excerpt illustrates the style:

According to the much debated theory proposed in 1980 by the team of Luis Alvarez and his son Walter, an asteroid or comet hit the earth at the end of the Cretaceous Era, 65 million years ago, hurling such a quantity of dust into the atmosphere that the sun was darkened for months. (p. 96)

"Viruses," adapted from Time Magazine (Wallis, 1986), concerns the effects of the AIDS virus on the body. It begins, "It is a tiny invader, more or less one sixteen thousandth of the size of a pin head, and it often penetrates a victim's bloodstream after sexual contact" (p. 66). The practice texts were similar to each kind of target text.

Questionnaire of metacognitive strategies. To ascertain whether participant awareness of strategies was affected by reading goal, we asked participants to complete a questionnaire. All participants received the same questionnaire but were asked to respond according to the reading purpose they had been given ("When reading for entertainment ..." or "When reading to study ..."). The questions included the following: When you feel that you have really understood something that you read, what does that mean? What sort of problems can occur in trying to comprehend, and is there anything you can do when one encounters such a problem? What sorts of problems do you think other people have most often in reading, and what would you tell them to do about these problems?

\section{Procedure}

Participants were randomly assigned to either the study or the entertainment condition. Both groups were told:

We are interested in how people read and in how we can design strategies for improving instruction. As a first step, we want to find out what good readers do when they read. Today, you will read several texts, and we will ask you about how you read. These questions are not about the specific texts, but about your reading experience in general. This is not an examination. We are only interested in what you do spontaneously.

The orientation for the study condition was the following:

Imagine that you are studying a text. For example, imagine that you want to learn the information in the text or that you are preparing for an examination. Try to imagine yourself where you would usually study, perhaps sitting in the library or in your room, studying the text.

Those in the entertainment condition were told:

Imagine that you are reading for pleasure. For example, you are at home, have made yourself comfortable, tumed on some nice music, and are now going to read a book. Or, you are at the lake on a nice sunny day, and you decide to read a magazine. Try to imagine yourself in a situation like thatpleasant, relaxed. You are reading for fun or pleasure. You can even sit how you would in a situation like that.
Participants were alone when tested. They completed the tasks in two sessions, one week apart. Each session took less than one hour.

Session 1. In the first session after orientation, participants practiced reading aloud with both an expository text and a narrative text. They were given examples of think-aloud comments and told to practice saying everything that passed through their minds while reading a text. The researcher reminded them to pause during reading to express their thoughts. After practicing reading the texts, the participants completed a questionnaire about reading strategies according to their reading purpose (study or entertainment). The participants then read two texts while thinking aloud: "Comet Fire" (the expository text) was read first, followed by "Spa" (the narrative text). The entire session was tape-recorded for later transcribing and scoring.

Session 2. In the second session, participants were asked to recall their orientation in the first session. To recreate their response set from the previous week, the participants were asked to read two new texts: "Viruses" and "All About Suicide." They were asked to record the time when they started and when they finished reading each text by referring to a clock in the room. When finished, they were asked to recall the texts they had read aloud the previous week. The participants then answered comprehension questions about the two new texts without referring to the texts. ' (See the Appendix for the questions and correct answers for both texts.)

\section{Scoring}

The think-aloud protocols were transcribed from the tapes and then scored for several categories of response by a researcher who was blind to the conditions. We used a categorization scheme similar to the one used by Zwaan and Brown (1996). The following are the categories, accompanied by examples from participant comments: (a) Associations include background knowledge associations (e.g., "This reminds me of a planetarium show I saw") and text-based associations (e.g., "Okay, this is in the spa"); (b) explanations include explanations based on background knowledge (e.g., "I think that is the cause of the ice age") and text-based explanations (e.g., "This must be what they meant by ash"); (c) predictions are forward inferences (e.g., "Okay, the gases will lead them to the actual object"); (d) evaluations are comments about the content of the text (e.g., "I think that's such a strong assertion"), on the writing of the text (e.g., "That sentence was difficult to say-it has too many words"), or on the reader's state (e.g., "I'm kind of losing track here, being distracted"); (e) text-based coherence breaks are statements about the coherence of the content of the text (e.g., "That doesn't make any sense"); (f) knowledge-based coherence breaks are statements about the reader's inability to understand due to lack of experience or knowledge (e.g., "It's kind of hard to imagine, I mean, in space"); and (g) repetitions are repetitions of words or phrases in the text.

The recall protocols were also scored by a judge who was blind to the conditions. The texts were parsed into clauses, and readers' protocols were matched against the original clauses. Credit was given for gist recall of a clause. Twenty percent of the think-aloud and recall protocols were scored by another judge. Interrater reliability kappa was .99 for recall and .95 for think-aloud

${ }^{1}$ Thus, this task served a dual purpose: to recreate the response set from the first session (Thorndyke, 1977) and to obtain on- and off-line measures to texts that were not influenced by think-aloud protocols. 
Table 1

Effect of Reading Purpose on Inference Generation: Sum of Ranks for Mann-Whitney $U$ Test and Significance for Each Inference Category

\begin{tabular}{|c|c|c|c|c|c|}
\hline \multirow[b]{3}{*}{ Inference category } & \multicolumn{4}{|c|}{ Purpose } & \multirow[b]{3}{*}{$p$} \\
\hline & \multicolumn{2}{|c|}{ Entertainment } & \multicolumn{2}{|c|}{ Study } & \\
\hline & $M$ & $S D$ & $M$ & $S D$ & \\
\hline Repetitions & .015 & .012 & .059 & .022 & .0001 \\
\hline $\begin{array}{l}\text { Coherence breaks: text } \\
\text { Coherence breaks: }\end{array}$ & .010 & .018 & .017 & .022 & $n s$ \\
\hline knowledge & .002 & .003 & .011 & .007 & .004 \\
\hline Evaluations & .052 & .020 & .111 & .045 & .004 \\
\hline Associations & .028 & .019 & .018 & .012 & $n s$ \\
\hline Explanations & .013 & .015 & .006 & .007 & $n s$ \\
\hline Predictions & .005 & .006 & .008 & .007 & $n s$ \\
\hline Total comments & .298 & .020 & .440 & .016 & $n s$ \\
\hline
\end{tabular}

Note. Numbers indicate the average frequency of each inference type, per participant and per statement.

aNumbers indicate the average number of comments per participant and per statement.

categories (both $p s<.01$ ). Disagreements were resolved through discussion.

The participants' answers to the questionnaire on reading strategies were scored according to three basic categories: (a) taking care of a problem while reading (e.g., rereading, slowing down, checking the context), (b) trying to resolve the problem after reading (e.g., making a note of it), and (c) ignoring a reading problem (e.g., reading on). The judges agreed $100 \%$.

\section{Results}

All statistical analyses were conducted with an alpha level of .05 per test and tests were two-tailed. We reported the results of nonparametric tests-Mann-Whitney U Test for between-group comparisons and Wilcoxon Sign Ranks Test for within-group comparisons.

\section{The Effect of Reading Purpose on Inferential Processes and Comprehension}

Reading purpose (study or entertainment) significantly affected three types of on-line responses: repetitions, knowledge breaks, and evaluations. Table 1 summarizes the results. The numbers in each column of Table 1 indicate the average number of inferences per participant and statement. Repetitions were more frequent in the study condition $(p<.0001)$. Although text-based coherence breaks were not affected by condition $(p<.370)$, knowledge-based coherence breaks were significantly more frequent in the study condition $(p<.004)$. For example, participants in the study condition more often made comments such as "I don't know, I still need more proof as to whether this, if it's really a comet fire, it seems like there's a lot of ways it could go besides a collision" or "I don't know what I just read" or "Well, why would they check all these different areas ... I mean, I guess I don't understand . . . I mean, it doesn't seem like a real random thing seeing as Denmark and Spain are both in Europe." In addition, participants made evaluative comments on content and writing more often in the study condition $(p<.004)$. For example, comments made include the following: "Now it seems to be making a lot more sense-easier to comprehend" or "This is a very strange story" or "This is really annoying-it's like it keeps shifting in verb tense or something."

There were no significant effects for the other inference types. Reading purpose did not affect the number of associations to either background knowledge or prior text material $(p<.201)$. Reading purpose did not significantly influence the number of explanations made by the reader $(p<.412)$, indicating that there is no evidence of differences in the number of backward causal inferences based on background knowledge or on the text. The number of predictions (forward inferences) was also not dependent on reading purpose $(p<.456)$. Although there were more comments per event in the study than in the entertainment orientation, this difference did not reach significance $(p<.112)$.

Table 2 presents the effects of reading purpose on the other measures: recall, comprehension following reading, and reading time. For the texts read normally for comprehension (i.e., without the think-aloud procedure), there were no differences in reading time $(p<.824)$ or in comprehension question responses $(p<.603)$ for the two conditions. For the off-line task of recall for the think-aloud texts, there were no differences by condition $(p<.261)$.

In summary, readers with a study purpose produced more repetitions, more acknowledgments of knowledge breaks, and more evaluations than did readers with an entertainment purpose. There were no differences in reading time, recall, or answers to comprehension questions as a function of reading purpose.

\section{The Effect of Reading Purpose on Inferential Processes and Comprehension as a Function of Text Type}

To determine whether the above effects of reading purpose were consistent across text types, we performed additional analyses with both reading purpose and text type as variables. First, we contrasted the two types of text. As can be seen in Table 3, reader responses differed according to text type with respect to several inference categories:

Table 2

Effect of Reading Purpose on Recall, Comprehension, and Reading Time

\begin{tabular}{|c|c|c|c|c|c|}
\hline \multirow[b]{3}{*}{ Measure } & \multicolumn{4}{|c|}{ Purpose } & \multirow[b]{3}{*}{$p$} \\
\hline & \multicolumn{2}{|c|}{ Entertainment } & \multicolumn{2}{|c|}{ Study } & \\
\hline & $M$ & $S D$ & $M$ & $S D$ & \\
\hline Recall & .065 & .056 & .100 & .062 & $n s$ \\
\hline Comprehension & .685 & .160 & .707 & .182 & $n s$ \\
\hline Reading time $^{\mathrm{a}}$ & 6.333 & 3.162 & 5.181 & 1.250 & $n s$ \\
\hline
\end{tabular}

Note. Cell means refer to average frequency per participant and per statement.

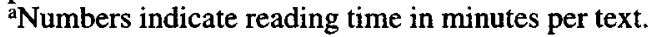


explanations, predictions, knowledge-based coherence breaks, evaluations, and associations. Readers produced more explanations $(p<.006)$ and more predictions $(p<.013)$ when reading the narrative text than when reading the expository text. For the expository text, more knowledge-based coherence breaks were expressed $(p<.011)$, as were more evaluations $(p<.01)$ and more associations $(p<.001)$. There were no significant differences in the number of repetitions made for the types of text $(p<.729)$, in the number of text-based coherence breaks reported $(p<.057)$, or in the number of comments per event $(p<.077)$.

Table 4 presents the effects of text type on the other measures: comprehension following reading and reading time. Reading time was affected by text type. Participants spent significantly $(p<.001)$ more time reading the expository text $(M=3.40 \mathrm{~min}, S D=1.39)$ than they did reading the narrative text $(M=2.30 \mathrm{~min}, S D=1.13)$, despite the fact that the former is shorter than the latter ( 23 sentences and 82 clauses for the expository text, and 31 sentences and 116 clauses for the narrative text). There were no differences as a function of text type in the off-line measures (recall of the texts read for think-aloud and question-answering for the text read silently).

Subsequently, we examined whether the effects of reading purpose differed across the two types of text. For three types of responses-evaluations, repetitions, and knowledgebased coherence breaks-the effects of reading purpose depended on text type. Table 5 provides the means, standard deviations, and significant $p$ values for these inference pattern differences. First, the group with a study purpose made more evaluative comments than did the group with an entertainment purpose while reading the expository text $(p<.001)$ but not while reading the narrative text $(p<.080)$. Second, those reading with a study purpose made more repetitions than those reading with an entertainment purpose while reading both the narrative and the expository texts, but this effect was stronger for the expository texts $(p<.0001)$ than for the narrative texts $(p<.016)$. Third, the group with

Table 3

Effect of Text Type on Inference Generation

\begin{tabular}{lllllll}
\hline & \multicolumn{5}{c}{ Type of text } \\
\cline { 2 - 3 } & \multicolumn{3}{c}{ Narrative } & \multicolumn{2}{c}{ Expository } & \\
\cline { 2 - 3 } \cline { 5 - 6 } \multicolumn{1}{l}{ Inference category } & $M$ & $S D$ & & $M$ & $S D$ & $p$ \\
\hline Repetitions & .030 & .013 & .050 & .013 & $n s$ \\
Coherence breaks: text & .015 & .021 & .013 & .021 & $n s$ \\
$\begin{array}{l}\text { Coherence breaks: } \\
\text { knowledge }\end{array}$ & .002 & .005 & .010 & .012 & .01 \\
Evaluations & .070 & .041 & .100 & .061 & .01 \\
Associations & .010 & .011 & .040 & .024 & .001 \\
Explanations & .020 & .015 & .004 & .008 & .006 \\
Predictions & .010 & .013 & .002 & .005 & .02 \\
Comments per event ${ }^{\mathrm{a}}$ & .030 & .021 & .040 & .019 & $n s$ \\
\hline
\end{tabular}

Note. Numbers indicate the average frequency of each inference type, per participant and per statement.

aNumbers indicate the average number of comments per participant and per statement.
Table 4

Effect of Text Type on Recall, Comprehension, and Reading Speed

\begin{tabular}{|c|c|c|c|c|c|}
\hline \multirow[b]{3}{*}{ Measure } & \multicolumn{4}{|c|}{ Type of text } & \multirow[b]{3}{*}{$p$} \\
\hline & \multicolumn{2}{|c|}{ Narrative } & \multicolumn{2}{|c|}{ Expository } & \\
\hline & $M$ & $S D$ & $M$ & $S D$ & \\
\hline Recall & .088 & .074 & .079 & .063 & $n s$ \\
\hline Comprehension & .700 & .242 & .717 & .221 & $n s$ \\
\hline Reading time ${ }^{a}$ & 2.300 & 1.139 & 3.400 & 1.392 & .001 \\
\hline
\end{tabular}

Note. Cell means refer to average frequency per participant and per statement.

a Numbers indicate reading time in minutes per text.

a study purpose expressed significantly more knowledgebased coherence breaks than did the group reading with an entertainment purpose during the reading of the expository text $(p<.004)$, whereas no such effect was obtained during the reading of the narrative text $(p<.552)$.

Furthermore, there was a significant difference between reading purpose and text type in their effects on reading time. There were no significant differences in reading time between the two reading purpose groups for either the narrative text or the expository text $(p<.196$ and $p<.453$, respectively). But the earlier finding that participants read the expository text slower than they read the narrative text (Table 4) was stronger for those reading with a study purpose $(p<.010)$ than for those reading with an entertainment purpose $(p<.024)$.

In summary, the effects of reading purpose partly depended on the type of text. Readers with a study purpose expressed more evaluations and knowledge-based coherence breaks in the think-aloud protocols than did readers with an entertainment purpose, but this difference was significant only for the expository text and not for the narrative text. Furthermore, readers with a study purpose included significantly more repetitions in the think-aloud protocol than did readers with an entertainment purpose, but this effect was stronger for the expository text than for the narrative text. Finally, readers with either reading purpose read the expository text more slowly than they read the narrative text, but the difference was greater for those reading with a study purpose. In general, the narrative text elicited more explanations and predictions than did the expository text. Conversely, readers produced more associations and more evaluations when reading the expository text than when reading the narrative text.

\section{The Effects of Reading Purpose on Readers' Awareness of Comprehension Strategies}

There were no significant differences between readers with different reading purposes in their responses to the questionnaire on reading strategies. This suggests that reading purpose did not affect the strategies that readers considered relevant to comprehension. However, the small sample size used in this study may have contributed to the null effect. 
Table 5

Effect of Reading Purpose and Text Type on Generation of Inferences and Reading Speed

\begin{tabular}{|c|c|c|c|c|c|c|c|c|}
\hline \multirow[b]{3}{*}{ Inference category } & \multicolumn{4}{|c|}{ Narrative } & \multicolumn{4}{|c|}{ Expository } \\
\hline & \multicolumn{2}{|c|}{ Entertainment } & \multicolumn{2}{|c|}{ Study } & \multicolumn{2}{|c|}{ Entertainment } & \multicolumn{2}{|c|}{ Study } \\
\hline & $M$ & $S D$ & $M$ & $S D$ & $M$ & $S D$ & $M$ & $S D$ \\
\hline Evaluations & .049 & .03 & .082 & .047 & .055 & .028 & .139 & $.055 * * *$ \\
\hline Repetitions & .018 & .022 & .041 & $.019^{*}$ & .012 & .006 & .077 & $.036 * * * *$ \\
\hline $\begin{array}{l}\text { Coherence breaks: } \\
\text { knowledge } \\
\text { Reading time }\end{array}$ & $\begin{array}{r}.001 \\
2.667\end{array}$ & $\begin{array}{r}.003 \\
1.414\end{array}$ & $\begin{array}{r}.003 \\
2.000\end{array}$ & $\begin{array}{r}.006 \\
0.775\end{array}$ & $\begin{array}{r}.003 \\
3.666\end{array}$ & $\begin{array}{r}.005 \\
1.871\end{array}$ & $\begin{array}{r}.019 \\
3.181\end{array}$ & $\begin{array}{l}.010^{* *} \\
0.874\end{array}$ \\
\hline
\end{tabular}

Note. Cell means indicate average frequency per participant per statement. Significance levels are based on Wilcoxon Signed Ranks Test of differences between reading purpose conditions.

${ }^{*} p<.016 . \quad * * p<.004 . \quad * * * p<.001 . \quad * * * * p<.0001$.

\section{Discussion}

The participants in this study were active in their reading. They "constructively responded" to the task of reading and thinking aloud (Pressley \& Afflerbach, 1995) with inferences and reactions to the text. Our data suggest several specific conclusions.

Reading purpose influenced the pattern of inferences that readers generated as they read. Readers with a study purpose were more likely to engage in repeating and evaluating the text and to indicate knowledge-based coherence breaks than were readers with an entertainment purpose. This pattern of findings corroborates readers' assessments of their own reading processes, in particular their perception that school (study) reading involves more rereading and attempts at integration (Lorch et al., 1993). The findings also suggest that the "search-after-meaning" principle (Graesser et al., 1994; van den Broek, 1990), according to which the reader attempts to explain each element in the text before continuing on to the next element, applies particularly to readers who are reading to study rather than to those who simply read for entertainment.

Furthermore, the fact that readers adjust their inferential activities to reflect a particular reading purpose, contradicts the view that inference generation during reading is a purely automatic, text-driven process. Although bottom-up processes certainly are involved (e.g., Kintsch \& van Dijk, 1978; McKoon \& Ratcliff, 1992), they are complemented, and possibly modified, by powerful influences from topdown processes originating from reader characteristics such as reading purpose.

Reading purpose influenced inferential activity during the reading of both types of text, but the above-mentioned patterns were more pronounced for the expository text than for the narrative text. Expository texts seem to evoke study-type behaviors, specifically the generation of repetitions and evaluations, as well as the identification of knowledge-based coherence breaks. Processing of narrative texts appears to be much less affected by reading purpose. Conversely, even though shorter, the expository text was read more slowly than the narrative text. These findings need to be interpreted with caution because they concern only one text of each type and hence may be caused by text properties other than type (narrative or expository). However, the patterns are intriguing because they raise the possibility that readers also adjust their inferential activities according to the type of text they are reading and that such adjustments interact with top-down reading goals. In particular, the patterns suggest that the comprehension processes that are elicited by having a study purpose are further strengthened if the text at hand is expository.

Regardless of reading purpose, readers gave more explanations and more predictions when reading the narrative text than when reading the expository. Conversely, the expository text evoked more associations, more repetitions, more evaluations and more indications of knowledge-based coherence breaks. Previous research provides various reasons for why one might expect different comprehension processes for narrative texts and expository texts: (a) Narrative texts may elicit more interest, promoting more explanations and predictions than do expository texts (e.g., Olson, Mack, \& Duffy, 1981; Schmalhofer \& Glavanov, 1986; Trabasso \& Magliano, 1996; van Dijk \& Kintsch, 1983); (b) narrative texts may promote increased inferencing, resulting, for example, in readers making nine times as many inferences during narrative texts as they made during expository texts (Graesser, 1981); (c) readers have early and extensive practice making inferences while reading narrative texts, because they are used when learning to read and because everyday life is constructed much like a story (Britton, Van Dusen, Glynn, \& Hemphill, 1990); (d) the structure of expository texts is more variable than that of narrative texts (Bock \& Brewer, 1985); (e) narrative texts may activate schema and script structures that support inference generation (Britton et al., 1990); and (f) narrative texts may rely more on familiar forms of causality than do expository texts, thus prompting more explanations and more predictive inferences. Circumstantial evidence that inferential activities indeed differ during the reading of narrative versus expository texts comes from findings that readers' memory representations for these types of texts differ (Einstein et al., 1990; Zwaan, 1994). The results of the present study provide a more direct indication that different text types may evoke different inferences and, furthermore, that such differences depend on the reader's goal.

Readers do not necessarily use strategies that help their reading purpose. Specifically, readers with a study purpose 
did not use more explanations than did those with an entertainment purpose, although increased use of explanation while reading expository text has been related to increased understanding (Chi, de Leeuw, Chiu, \& LaVancher, 1994). The fact that the readers with a study purpose did not use explanations more frequently lends support to speculations that readers do not automatically use the best strategies when studying and that they need assistance in learning these strategies (Spring, 1985). For example, Spring studied a group of university freshman that included both good and poor readers. The participants were asked to rate the frequencies with which they applied particular text-processing strategies while reading textbooks. The factor analysis distinguished between comprehension strategies (those used to identify causal relations) and study strategies (those used to remember the text after comprehension, such as asking questions or outlining). Reading strategies in which causal relations were central were related to better reading comprehension (see also van den Broek \& Kremer, in press). In the present study, the narrative text evoked more explanations and predictions, as well as behaviors linked to causal understanding and to increased reading comprehension (Palincsar \& Brown, 1984; Trabasso \& Magliano, 1996). Readers in the study condition (especially with the expository text) used the study strategies that Spring found less effective for comprehension. They did not use methods that support the "transformation" of knowledge into the type of mental representation that promotes long-term learning (Scardamalia \& Bereiter, 1984).

The results suggest several educational implications. First, instructors, curriculum writers, and students need to realize that associative elaborations alone cannot cause learning to take place (see Trabasso \& Magliano, 1996). Explanatory inferences are also vital (e.g., van den Broek \& Kremer, in press). Second, texts and instructors need to ask the questions that will lead the reader to make inferences that are related to increased retention, such as causal relations between elements of the text, predictions, and explanations. Students naturally perform these behaviors with narrative texts and need to activate such strategies when studying. Third, readers need to be coached to monitor their comprehension strategies and activate comprehension-enhancing techniques. Our results show that such training is particularly important if students' comprehension of expository texts is to be successful.

\section{References}

Anderson, R. C., \& Pichert, J. W. (1978). Recall of previously unrecallable information following shift in perspective. Journal of Verbal Learning and Verbal Behavior, 17, 1-12.

Angier, N. (1985, October 14). Comet fire. Time, 126, 92.

Bock, J. K., \& Brewer, W. (1985). Discourse structure and mental models. In D. Carr (Ed.), Development of reading skills (pp. 55-75). San Francisco: Jossey-Bass.

Britton, B. K., Van Dusen, L., Glynn, S. M., \& Hemphill, D. (1990). The impact of inferences on instructional text. The Psychology of Learning and Motivation, 25, 53-70.

Chi, M. T. H., de Leeuw, N., Chiu, M., \& LaVancher, C. (1994).
Eliciting self-explanations improves understanding. Cognitive Science, 18, 439-477.

Chi, M. T. H., Feltovich, P. J., \& Glaser, R. (1981). Categorization and representation of physics problems by experts and novices. Cognitive Science, 5, 121-152.

Chiesi, H. L., Spilich, G. J., \& Voss, J. F. (1979). Acquisition of domain-related information in relation to high and low domain knowledge. Journal of Verbal Learning and Verbal Behavior, 18, 257-274.

De Vega, N. (1990). Lectura y comprension: Una perspectiva cognitiva. Madrid, Spain: Alianza Editorial.

Einstein, G. O., McDaniel, M. A., Owen, P. D., \& Coté, N. C. (1990). Encoding and recall of texts: The importance of material appropriate processing. Journal of Memory and Language, 29, 566-581.

Gaite, C. M. (1993). El balneario. Madrid, Spain: Alianza Editorial.

Goldman, S., \& Varma, S. (1995). CAPping the constructionintegration model of discourse. In C. A. Weaver III, S. Mannes, \& C. R. Fletcher (Eds.), Discourse comprehension: Essays in honor of Walter Kintsch (pp. 337-358). Hillsdale, NJ: Erlbaum.

Graesser, A. C. (1981). Prose comprehension beyond the word. New York: Springer-Verlag.

Graesser, A. C., Singer, M., \& Trabasso, T. (1994). Constructing inferences during narrative text comprehension. Psychological Review, 101, 371-395.

Horiba, Y. (1990). Narrative comprehension processes: A study of native and nonnative readers of Japanese. Modern Language Journal, 74, 187-202.

Horiba, Y., van den Broek, P., \& Fletcher, C. R. (1993). Secondlanguage readers' memory for narrative texts: Evidence for structure-preserving top-down processing. Language Learning, $43,345-372$.

Kintsch, W., \& van Dijk, T. A. (1978). Toward a model of text comprehension and production. Psychological Review, 85, 363-394.

Lorch, R. F., Lorch, E. P., \& Klusewitz, M. A. (1993). College students' conditional knowledge about reading. Journal of Educational Psychology, 85, 239-252.

Lundeberg, M. A. (1987). Metacognitive aspects of reading comprehension: Studying understanding in legal case analysis. Reading Research Quarterly, 22, 407-432.

McDaniel, M. A., Einstein, G. O., Dunay, P. K., \& Cobb, R. E. (1986). Encoding difficulty and memory: Toward a unifying theory. Journal of Memory and Language, 25, 645-656.

McKoon, G., \& Ratcliff, R. (1986). Inferences about predictable events. Journal of Experimental Psychology: Learning, Memory, and Cognition, 12, 82-91.

McKoon, G., \& Ratcliff, R. (1992). Inferences during reading. Psychological Review, 99, 440-466.

Murray, J. D., Klin, C. M., \& Myers, J. L. (1993). Forward inferences in narrative text. Journal of Memory and Language, $32,464-473$.

O'Brien, E. J., Shank, D. M., Myers, J. L., \& Rayner, K. (1988). Elaborative inferences during reading: Do they occur on-line? Journal of Experimental Psychology: Learning, Memory and Cognition, 14, 410-420.

Olson, G. M., Mack, R. L., \& Duffy, S. A. (1981). Cognitive aspects of genre. Poetics, 10, 283-315.

Palincsar, S., \& Brown, A. (1984). Reciprocal teaching of comprehension-fostering and comprehension-monitoring activities. Cognition and Instruction, 1, 117-175.

Pichert, J. W., \& Anderson, R. C. (1977). Taking different perspectives on a story. Journal of Educational Psychology, 69, 309-315.

Pressley, M., \& Afflerbach, P. (1995). Verbal protocols of reading: 
The nature of constructively responsive reading. Hillsdale, NJ: Erlbaum.

Scardamalia, M., \& Bereiter, C. (1984). Development of strategies in text processing. In H. Mandl, N. L. Stein, \& T. Trabasso (Eds.), Learning and comprehension of text (pp. 379-406). Hillsdale, NJ: Erlbaum.

Schmalhofer, F., \& Glavanov, D. (1986). Three components of understanding a programmer's manual: Verbatim, propositional, and situational representations. Journal of Memory and Language, 25, 279-294.

Singer, M. (1994). Discourse inference processes. In M. A. Gernsbacher (Ed.), Handbook of psycholinguistics (pp. 479516). New York: Academic Press.

Spring, C. (1985). Comprehension and study strategies reported by university freshmen who are good and poor readers. Instructional Science, 14, 157-167.

Thorndyke, P. W. (1977). Cognitive structures in comprehension and memory of narrative discourse. Cognitive Psychology, 9, 77-110.

Trabasso, T., \& Magliano, J. P. (1996). Conscious understanding during comprehension. Discourse Processes, 21, 255-288.

Trabasso, T., \& Suh, S. (1993). Understanding text: Achieving explanatory coherence through on-line inferences and mental operations in working memory. Discourse Processes, 16, 3-34.

Trabasso, T., van den Broek, P., \& Suh, S. (1989). Logical necessity and transitivity of causal relations in stories. Discourse Processes, 12, 1-25.

Valenzuela, L. (1988). The censors. Willimantic, CT: Curbstone Press.

van den Broek, P. (1990). The causal inference maker: Towards a process model of inference generation in text comprehension. In D. A. Balota, G. B. Flores d'Arcais, \& K. Rayner (Eds.), Comprehension processes in reading (pp. 423-445). Hillsdale, NJ: Erlbaum.

van den Broek, P., Fletcher, C. R., \& Risden, K. (1993). Investigations of inferential processes in reading: $A$ theoretical and methodological integration. Discourse Processes, 16, 169-180. van den Broek, P., \& Kremer, K. (in press). The mind in action: What it means to comprehend. In B. Taylor, P. van den Broek, \& M. Graves (Eds.), Reading for meaning. New York: Teachers College Press.

van den Broek, P., Rohleder, L., \& Narvaez, D. (1996). Cognitive processes in the comprehension of literary texts. In $\mathrm{H}$. van Oostendorp \& R. Zwaan (Eds.), Naturalistic text comprehension: Vol. 53. Advances in discourse processes (pp. 229-246). Norwood, NJ: Ablex.

van Dijk, T. A., \& Kintsch, W. (1983). Strategies of discourse comprehension. New York: Academic Press.

Walker, C. H., \& Meyer, B. J. F. (1980). Integrating different types of information in text. Journal of Verbal Learning and Verbal Behavior, 19, 263-275.

Wallis, C. (1986, November 3). Viruses. Time, 128, 66-73.

Whitney, P., Ritchie, B. G., \& Clark, M. B. (1991). Workingmemory capacity and the use of elaborative inferences in text comprehension. Discourse Processes, 14, 133-146.

Wineberg, S. S. (1991). On the reading of historical texts: Notes on the breach between school and academy. American Educational Research Journal, 28, 495-520.

Wolman, C. (1991). Sensitivity to causal cohesion in stories by children with mild mental retardation, children with learning disabilities, and children without disabilities. Journal of Special Education, 25, 135-154.

Wolman, C., van den Broek, P., \& Lorch, R. (1997). Effects of causal structure on immediate and delayed story recall by children with mild mental retardation, children with learning disabilities, and children without disabilities. Journal of Special Education, 30, 439-455.

Zwaan, R. A. (1994). Effect of genre expectations on text comprehension. Journal of Experimental Psychology: Learning, Memory, and Cognition, 20, 920-933.

Zwaan, R. A., \& Brown, C. M. (1996). The influence of language proficiency and comprehension skill on situation-model construction. Discourse Processes, 21, 289-328. 


\section{Appendix}

\section{Comprehension Questions}

\section{Comprehension Questions and Correct Responses for "Viruses"}

1. How big is the AIDS virus when it gets into the blood stream? One sixteen thousandth of the size of a pin head.

2. What did the "tulipmania" consist of?

An infection in tulip bulbs produced a new variety of flower with spectacular color combinations, giving rise to a financial crisis in Holland in the seventeenth century.

3. In general terms, what is the effect of the AIDS virus on the organism?

The AIDS virus defeats the immune system, making it vulnerable to diseases normally defeated by the immune system.

4. What did Ramses $V$ died of?

Smallpox.

5. What's the initial composition of the AIDS virus when it enters the organism?

An RNA strand and a double-layered protein envelope.

6. What does the text say about the effect of the virus on humanity?

Viruses have been killing humans for thousands of years.

7. What are the cells called "macrophages"?

The macrophage is the large explorer cell of the immune system.

8. What happens a half an hour after the AIDS virus becomes embedded in the membrane of the immune system's T-cell?

The RNA strand and an accompanying enzyme will be floating in the cytoplasm of the cell.

9. What is the principal transformation caused by the AIDS virus once it enters the organism, and what is the effect of this transformation?

The AIDS virus converts its RNA into DNA and takes charge of the cell's machinery, creating more viruses. The cell eventually swells and dies, releasing more viruses.

\section{Comprehension Questions and Correct Responses for "All About Suicide"}

1. How many drinks did Ismael have before deciding to kill himself?

Three.

2. In what location was the trigger of the revolver pulled?

In an office.

3. What death is referred to (or explained) in the text?

Ismael's death.

4. Where was the revolver found?

In his desk drawer.

5. Why does the protagonist consider the decision to die irrevocable?

There is no way to go back and change it.

6. What is the sequence of actions leading up to the pulling of the trigger?

He enters the building, says hello to the guard, opens the door to his office, goes to his desk, takes the revolver out of a drawer, rubs it against his temple.

7. What was the writing table/desk covered by?

Glass.

8. What is the experience of the protagonist after pulling the trigger?

Almost sensual and quite unexpected.

9. What motives are offered to explain the firing of the revolver? He couldn't tell what he knew about his former friend, now a minister and a traitor.

Received November 15, 1997

Revision received November 23, 1998

Accepted November 23, 1998 